\title{
Distribusi dan pemetaan Varian-Varian Bahasa Mbojo di Kabupten Sumbawa
}

\author{
Siti Djuwarjiah*)
}

\begin{abstract}
Abstrak
Tujuan penelitian ini adalah memaparkan distribusi dan pemetaan varian-varian bahasa Mbojo di Kabupaten Sumbawa. Pendekatan yang dipakai adalah pendekatan dialektologi diakronis. Terdapat lima buah enklave bahasa Mbojo di Kabupaten Sumabawa. Kelima enklave tersebut terletak di sisi utara Kabupaten Sumbawa, Yakni Desa Karangbagik di Kecamatan plampang dan Desa Labu Lopok, Desa Usar di Kecamatan plampang dan Desa Labu Bontong di Kecamatan Tarano. Bahasa Mbojo yang ada di Kabupaten Sumbawa (MBS) memiliki dua dialek, yaitu dialek Mbojo Motong Karangbagik (DMbMK) dan Dialek Mbojo Labuan Bontong (DMbLb). Dua subdialek dari DMbMK, yakni subdialek Montong (MbM) dan subdialek Karangbagik (MbK). Sementara MbK memiliki dua perbedaan wicara, hakni Mbojo Usar (MbUS) dan Mbojo Hijrah (MbHj).
\end{abstract}

Kata Kunci: enlave, dialek, subdialek, beda wicara

\section{Pengantar}

Bangsa Indonesia merupakan bangsa yang terdiri dari atas berbagai suku bangsa. Keberagaman suku bangsa menumbuhkan pula keberagaman bahasa dan budaya. Keberagaman ini memunculkan pertanyaan mendasar apa, berapa dan di mana saja bahasa dan budaya tersebut berkembangan. Selanjutannya, adanya gerak dan arah perpindahan suku bangsa keluar dari wilayah asal kemudian menempati wilayah lain, yang kita kenal dengan, migrasi, memunculkan adanya perpindahan bahasa. Artinya, bila penuturannya bermigrasi, bahasa itu pun turut terbawa bermigrasi. Asumsi yang berlaku adalah wilayah suatu bahasa dianggap sama dengan daerah penuturan-penutur bahasa tersebut. Daerah yang baru didatangi oleh penutur bahasa yang bermigrasi disebut intrusi migratoris (1986).

Suatu Proses yang terjadi adalah sejumlah penutur bahasa bergerak keluar wilayah asli dan menduduki suatu daerah baru. Proses ini disebut dengan migrasi positif. Suku bangsa Mbojo yang menghuni sebelah timur pulau Sumbawa berpindah dan menempati wilayah baru di Kabupaten Sumbawa yang berada sebelah barat pulau Sumabawa. Suku bangsa Mbojo yang 
menghuni wilayah Kabupaten Bima dan Kabupaten Dompu bergerak memasuki wilayah administrasi Kabupaten Sumbawa. Masyarakat Mbojo adalah komunitas yang memiliki mobilitas yang sangat tinggi. Mereka suka berrpindah-pindah dari satu tempat ke tempat lain. (Mahsun, 2005).

Suku bangsa Mbojo atau yang di kenal dengan dou mbojo membentuk kantong-kantong pemukiman. Kantong-Kantong pemukiman ini membentuk adanya kantong-kantong bahasa atau enklave. Kelima enklave tersebut terletak di sisi utara Kabupaten Sumbawa, yakni Desa Montong Kecamatan Utan, Desa Karangbagik Kecamatan Sumbawa, Desa Hijrah di Kecamatan Lape Lopok, Desa Usar di Kecamatan Plampang dan Desa Labu Bontong di Kecamatan Tarano. Kecamatan Tarano merupakan lokasi paling timur dan berbatasan dengan Kabupaten Dompu, sedangkan lokasi paling barat adalah adalah Desa Montong Kecamatan Utan.

Tercatat ada beberapa penelitian sebelumnya yang membahas bahasa Mbojo, di antaranya oleh Heru Santoso (1987) Mengenai Pemetaan Bahasa-Bahasa di Nusa Tenggara Barat. Penelitian yang lain dilakukan oleh Syamsudin AR (199) dan Haris (1995) adalah penelitian yang banyak dilakukan secara sinkronis, yakni hanya membahas aspek-aspek tertentu bahasa Mbojo. Aspek yang dibahas adalah aspek fonologi dan aspek morfologi. Penelitian lain yang mencoba menggunakan pendekatan diakronis adalah Syamsudi AR (1996).

Beberapa penelitian sebelumnya yang didasari pada dialektologi diakronis dilakukan oleh Sudika (1998) berjudul Isolek Bahasa Bali di Lombok: Suatu Kajian Dialektologi yang mengkaji distribusi bahasa Bali di Pulau Lombok. Disertasi Dhanawati (2012) yang berjudul Variasi Dialektal Bahasa Bali di Daerah Transmigrasi Lampung Tengah mengkaji bahasa Bali yang ada di daerah kantong bahasa Bali di Lampung dan Burhanudin (2005) dalam tesisnya yang berjudul Enklave Sumbawa di Pulau Lombok: Kajian Linguistik Diakronis yang membahas enklave bahasa Sumabawa di pulau Lombok.

Telaah kajian dialekronis belum banyak dilakukan. Mengingat banyaknya suku bangasa dan adanya migrasi dari suku bangasa tersebut, maka kajian dialektologi diakronis merupakan bidang kajian yang sangat terbuka di Provinsi Nusa Tenggara Barat pada umumnya dan Kabupaten Sumbawa pada khususnya. Kabupaten Sumbawa dihuni oleh suku bangsa lain, di antaranya Jawa, Madura, Bali, Bugis, Bajo, dan Selayar. Kantong-Kantong bahasa yang ada tersebut merupakan suatau hal yang menarik untuk dibahas dan penelitian ini belum dilakukan sebelumnya. 
Sehubungan dengan belum danya penelitian tentang bahasa Mbojo sebelumnya yang ada di Kabupaten Sumbawa, penelitian yang dilakukan ini merupakan penelitian dialektologi yang penekananya pada berapakah varian pada masing-masing isolek Mbojo di Kabupaten Sumbawa; bagaimanakah hubungan kekerabatan antara isolek Mbojo yang satu dengan isolek Mbojo yang lainnya yang ada di Kabupaten Sumbawa; dn bagaimanakah sebaran geografis isolek Mbojo di Kabupaten Sumbawa.

Metode yang digunakan dalam pengumpulan data dalam penelitian ini adalah metode cakap dengan teknik cakap semuka, teknik catat, dan tenik tekam. Adapun instrumen yang digunakan sebagai pedoman wawancara adalah instrumen berupa daftar tanyaan yang sudah ditetapkan oleh pusat Bahasa, yaitu berisi 200 kosakata swadesh dan 335 kosakata budaya.

Metode yang dipakai dalam penelitian ini menggunakan pendekatan dialektologi diakronis yang meliputi metode kuantitaif berupa perhitungan dialektromentri dan digunakan pula bukti kualitatif untung mendukung perhitungan dialektromentri tersebut.

\section{Pembahasan}

Setelah menganalisis 535 kosakata, 200 kosakata dasar, dan 335 sisanya adalah kosa kata budaya dasar, teridentifikasi sebanyak 185 buah peta perbedaaan unsur-unsur kebahasaaan yang mencakup bidang fonologi dan leksikon. Lima puluh enam data merupakan perbedaan pada bidang fonologi yang terbagi dalam kaidah korespondensi dan variasi, baik vokal maupun konsonan, sedangkan perbedaan leksikon sebanyak 31 data.

\subsection{Penentuan Isolek Sebagai Dialek dan Subdialek}

Penentuan isolek sebagai dialek atau subdialek agar diperoleh gambaran yang jelas mengenai hubungan yang terdapat antara isolek yang digunakan pada setiap daerah pengamatan. Untuk mencapai tujuan tersebut, upaya yang dilakukan adalah menghitung jumlah isoglos yang berfungsi yang menyatukan daerah-daerah pengamatan yang menampilkan gejala kebahasaan yang serupa itu dijadikan landasan dalam menentukan isolek dialek atau subdialek.

Penentuan dialek atau subdialek bahasa Mbojo di Kabupaten Sumbawa dengan menggunkan metode kuantitatif yakni dialektromentri dan metode ini saling melengkapi. Hasil perhitungan menggunakan metode dialektomentri dijadikan dasar penentuan isolek-isolek menjadi dialek atau subdialek. Namun, jika kuantitatif ini memisahkan suatu isolek dengan 
lainnya sebagai bahasa yang berbeda, bukti kuantitatif yang berupa inovasi bersma digunakan sebagai bahan pertimbangan penyatuan kembali isolek-isolek tersebut menjadi satu bahasa.

Penentuan dialek di atas didasarkan pada perhitungan dialektrometri berikut ini.

\begin{tabular}{|l|l|l|l|}
\hline No. & $\begin{array}{l}\text { Dearth yang di } \\
\text { bandingkan }\end{array}$ & Dialektometri & $\begin{array}{l}\text { Status } \\
\text { Isolek }\end{array}$ \\
\hline 1 & $1-2$ & $37 \%$ & Subdialek \\
\hline 2 & $1-3$ & $28 \%$ & Wicara \\
\hline 3 & $1-4$ & $38 \%$ & Subdialek \\
\hline 4 & $1-5$ & $78 \%$ & Dialek \\
\hline 5 & $2-3$ & $39 \%$ & Subdialek \\
\hline 6 & $2-4$ & $43 \%$ & Subdialek \\
\hline 7 & $2-5$ & $80 \%$ & Dialek \\
\hline 8 & $3-4$ & $29 \%$ & Wicara \\
\hline 9 & $3-5$ & $78 \%$ & Dialek \\
\hline 10 & $4-5$ & $68 \%$ & Dialek \\
\hline
\end{tabular}

Berdasarkan perhitungan dialektometri di atas, dapat dijelaskan terdapat tiga tingkat perbedaan yakni beda dialek, beda subdialek dan beda wicara. Semakin kecil persentase angkanya, maka masing-masing daerah pengamatan semakin dekat kekerabatannya. Dari hasil perhitungan bahasa Mbojo di Kabupaten Sumbawa, tidak memunculkan bahasa tersendiri. Persentase yang termasuk dalam kriteria beda bahasa harus di atas $80 \%$. Pada tataran beda dialek akan terlihat bahawa daersh pengamatan 5 memiliki persentase yang tinggi, yakni antara $50 \%$ hingga $80 \%$. Perbandingan daerah pengamatan 1 dan 5 adalah $78 \%$, daerah pengamatan 2 dan 5 adalah $80 \%$, dan daerah pengamatan 4 dan 5 adalah 68\%. Dari data yang ada, dapat di simpulkan daerah pengamatan 5 merupakan dialek tersendiri.

Persentase yang termasuk kategori beda subdialek adalah anatara 31\% sampai dengan 50\%. Pada tataran beda subdialek di temuakan sebanyak 4 buah, yakni perbandingan antara daerah pengamatan 1 dan 2 sebesar 37\%, daerah pengamatan 1 dan 4 sebesar 38\%, daerah pengamatan 2 dan 3 sebesar 39\%, dan daerah pengamatan 2 dan 4 sebesar $43 \%$. Berdasarkan persentse dapat disimpulkan adanya satu dialek yang menurunkan 2 subdialek, yakni daerahpengamatan 1 dan daerah pengamatan 2 . 
Persentase yang termasuk dalam kategori beda wicara adalah antara 21\%--30\%. Pada tataran beda wicara, ditemukan dua buah, yakni perbandingan antara daerah pengamatan 1 dan 3 sebesar 28\% dan daerah pengamatan 3 dan 4 sebesar 29\%. Data yang ada menunjukan bahwa daerah pengamatan 3 dan 4 mempunyai status yang lebih rendah, yakni beda wicara.

Adanya beda wicara berkaitan dengan asal subdialek. Subdialek yang ditemui adalah daerah pengamatan 1 dan 2. Dasar pertimbangan untuk menentukan kedekatan kekerabatan adalah besaran persentase yang lebih kecil. Berdasarkan perhitungan, daerah pengamatan 3 dan 4 sebagai sebuah subdialek.

Penentuan isolek-isolek di atas menjadi dua dialek seperti yang telah disajikan, selain berdasarkan perhitungan dialektomentri dan inovasi bersama juga dapat dibuktikan dengan banyaknya isoglos yang menyatuhkan atau memisahkan kedua dialek tersebut. Isoglos yang mempersatukan daerah-daerah dialek di atas dapat dijelaskan sebagai berikut. Penetuan isolek dapat juga dilakukan dengan bukti-bikti kualitatif, yakni dengan pembuktian adanya data korespondensi. Korespondensi sebagai suatu keteraturan diasumsikan seperti bahasa yang memiliki keteraturan. Selain itu, juga akan dipaparkan perbedaan yang berupa variasi dan perbedaan leksikon yang menyatukan masing-masing isolek tersebut.

Data yang menyatukan daerah pengamatan 1-4 sekaligus membedakan daerah pengamatan 5, yakni berupa korespondensi yang berjumlah 10 buah peta, variasi yang berjumlah 17 buah, dan perbedaan leksikon yang berjumlah 27 buah. Jumlah keseluruhan adalah 50 buah peta atau sebesar $31 \%$ dari totoal peta perbedaan.

Data yang menyatukan daerah pengamatan 1-2 yaitu berupa korespondensi yang berjumlah 10 buah peta, variasi yang berjumlah 24 buah peta, dan perbedaan leksikon sebanyak 13 buah. Jumlah keseluruhan adalah 46 buah peta atau sebesar 29\% dari totoal peta perbedaan.

Data yang menyatuhkan daerah pengamayan 3 dan 4, yakni berupa korespondensi sejumlah 6 buah peta, variasi sebanyak 20 buah peta, dan perbedaan leksikon sebanyak 20 buah. Jumlah keseluruhan adalah 46 buah peta tau sbesar $29 \%$ dari total peta perbedaan. 
Didasarkan pada pengelompokan yang dipakai dalama metode penentuan dialekl/subdialek, dapat disimpulkan bahwa bahasa Mbojo di Kabupaten Sumbawa (MbS) memiliki 2 dialek, yaitu:

1) Daerah dialek Mbojo Motong Karangbagik (DMbMK), yaitu daerah pengamatan 1, 2, 3, dan 4.

2) Dialek Dialek Mbojo Labuan Bontong (DMblb), yaitu daerah pengamatan 5

Sebaran geografis kedua dilek tersebut bisa dilihat pada peta di bawah ini.

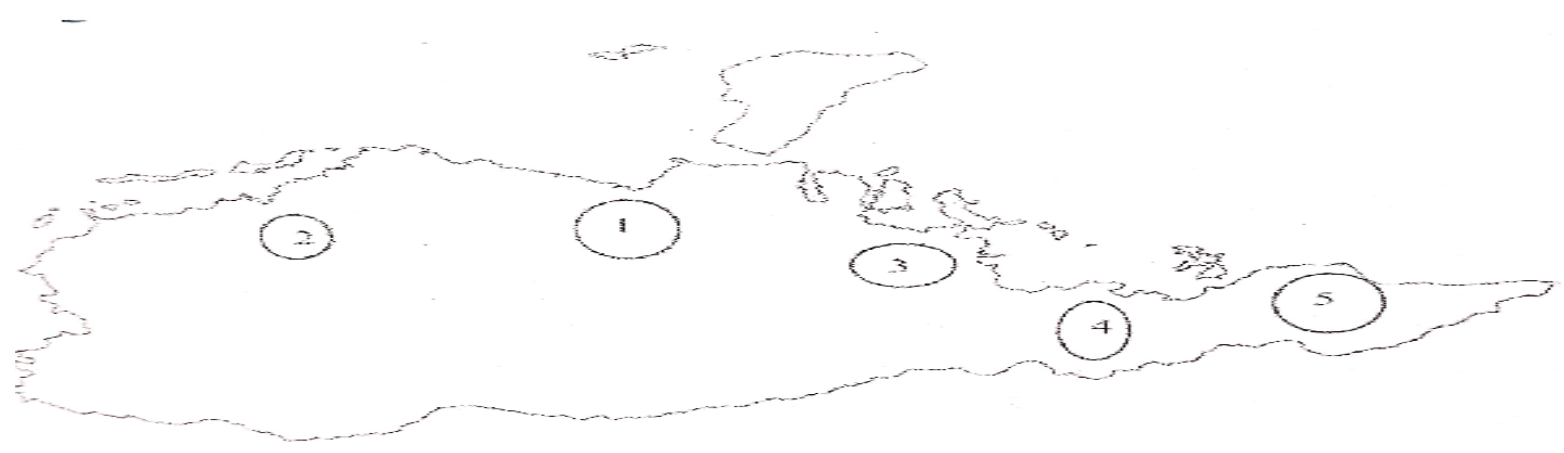

Keterangan: 1. Subdialek Motong (MbM)

2. subdialek Karangbagik,(MbK)

3. beda wicara Mbojo Usar ( MbUs)

4. beda wicara Mbojo Hijrah (MbH)

5. dialek Mbojo Labuan Bontong ( DMbLb)

\subsection{Penentuan Status Kekerabatan}

Bedasarkan perhitungan dialektometri, diperoleh gambaran bahwa bahasa Mbojo yang ada di Kabupaten Sumabawa (MBS) memiliki dua dialek, yaitu dialek Mbojo Karangbagik (DMbMK) dan Dialek Mbojo Labuan Bontong (DMbLb). Dua subdialek Motong (MbM) dan subdialek Karangbagik (MbK). Sementara subdialek Karangbagik (MbK) memiliki dua 
perbedaan wicara, yakni Mbojo Usar (MbUs) dan Mbojo Hijrah (MbHj). Secara kualitatif, penemuan isolek-isolek tersebut melalui jenjang kekerabatan yang bertingkat. Pohon kekerabatan berikut dapat memperjelasnya.

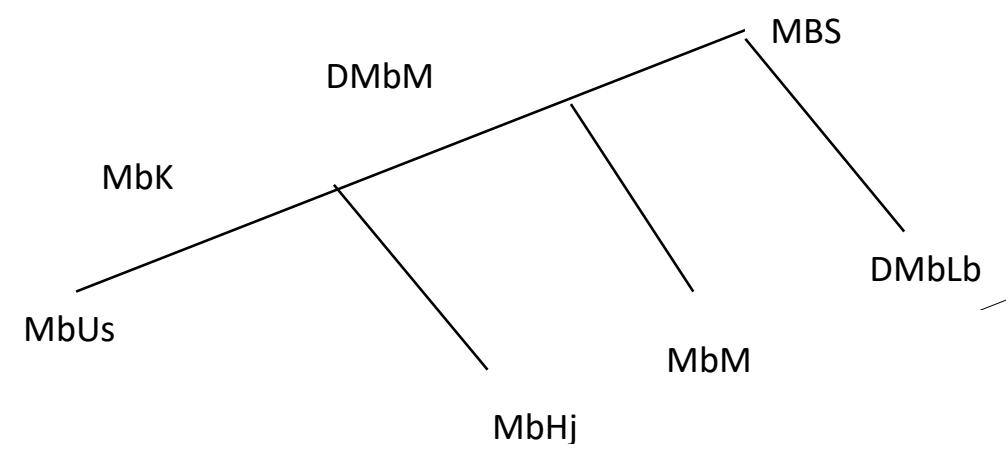

\subsection{PengenalanDialekMbojoontongKrangbagik}

Pada bagian ini akan, dipaparkan sistem fonologi dari dialek Bahasa Mbojo Sumbawa. Fonem-fonem dialek Mbojobojo Montong Karangbagik pada dasarnya dapat dikelompokkan menjadi dua bagian, yaitu vokal dan konsonan. Paparan ini diharapankan memberikan gambaran yang jelas tentang keadaan dialek Mbojo Montong. Dasar pertimbangan paparan ini adalah bahwa dialek Montong Karangbagik merupakan dialek dengan daerah cukupan yang pling banyak sehingga dapata dijadikan acuan. Berikut akan dipaparkan mengenai vokal, konsonan dan distribusinya.

\subsubsection{Vokal Dialek Montong Karangbagik}

Berdasarkan identifikasi sistem morfologi bahwa bunyi bahasa (fonem) dalam dialek Mbojo Motong Karangbagik berjumlah 26 buah, terdiri atas 5 buah fonem vokal dan 21 buah fonem konsonan. Kelima Vokal tersebut adalah /i/, /u/, /e/, /o/,dan /a/.

Pembuktian akan status fonemis kedelapan vokal di atas dilakukan dengan menunjukan pasangan minimal dari fenom-fenom tersebut dan fenom-fenom yang tidak ditemukan pasangan minimal dari fenom-fenom tersebut, dengan catatan, bunyi yang dimilki distribusi yang lengkap atau unik, dianggap sebagai fenom yang berdiri sendri, bukan alofon dari sebuah fenom. Untuk memperjelaskan keberadaan kelima bunyi vokal dimaksud, berikut diuraikan contoh dalam bentuk pasangan minimal.

a. $[$ abo] $<$ 'goyang “ / o / 
[abu] " bengkak, kakak atau ayah yang sudah ........................../ u/

b. [ada] "adat " ...................................................................... a/

[adi] "adil " ........................................................................ /i/

c. [ede] "jenis pohon" .........................................................../u/

$[\mathrm{edu}]$ "jenis pohon" .........................................................../u/

Fenom /i/ merupakan fenom vokal tinggi depan tak bundar, fenom /u/ merupakan fenom vokal tinggi-belakang bundar, fenom /e/ merupakan fenom vokal pusat-depan tak bundar, dan fenom /o/ merupakan fenom puasat-belakang bundar. Penjelasan lebih lanjut bahwa bunyi /o/ dan /e/ masing-masing hanya memiliki dua variasi alofonis.

Fenom vokal ringgi-depan /i/ memilki dua alofon yaitu /I/ dan /i/. Fenom /i/ dilafalka sebagai /i/ apabila muncul posisi silabe terbuka dan akan diucapkan sebagai /i/ apabila muncul posisi sibale terbuka dan akan diucapkan sebagai /I/ jika diikuti konsonan, kecuali glotal, baik pada suatu silabe maupun pada silabe yang berbeda dalam satu kata seperti pada contoh berikut ini.

\begin{tabular}{|c|c|c|c|}
\hline vokal & alofon & Contoh & silabe \\
\hline \multirow{6}{*}{ /i/ } & \multirow{3}{*}{ /i/ } & [ilu] 'hodung' & Terbuka \\
\hline & & [kalai]' memisah' & Terbuka \\
\hline & & [kalglpi 'kencangkeras' & Terbuka \\
\hline & \multirow{3}{*}{ /I/ } & [slnci] 'cincin' & Tertutup \\
\hline & & [karldndi] 'beberapa' & Tertutup \\
\hline & & [Ilmbi 'benar' & tertutup \\
\hline
\end{tabular}

Fenom vokal /u/ memiliki dua alofon, yaitu [u] dan [U]. Fenom [u] akan dilafalkan sebagai [u] apabila muncul pada silabe terbuka dan dilafalkan [U] apabil diikuti konsonan, baik dalam satu silabe maupun pada silabe yang berbeda dalam satu kata, kecuali diikuti glotal. Penjelasan lebih lanjut dapat dilihat pada tabel berikut ini.

\begin{tabular}{|l|l|l|l|}
\hline vokal & alofon & Contoh & silabe \\
\hline \multirow{3}{*}{} & \multirow{3}{*}{$/ \mathrm{u} /$} & {$[\mathrm{uma}]$ 'rumah' } & Terbuka \\
\cline { 3 - 4 } & {$[$ kalau] 'kelihatan' } & Terbuka \\
\hline
\end{tabular}




\begin{tabular}{|l|l|l|l|}
\hline /e/ & & {$[$ afuka] 'pengacara' } & Terbuka \\
\cline { 2 - 4 } & \multirow{3}{*}{ /U/ } & {$[\mathrm{Umpu}]^{\prime}$ 'siput' } & Tertutup \\
\cline { 3 - 4 } & {$[$ karUmpa] 'terompah' } & Tertutup \\
\cline { 3 - 4 } & {$[\mathrm{kabUsu}]$ 'ubun' } & Tertutup \\
\hline
\end{tabular}

Vokal tengah-depan memeiliki dua alfon yaitu [e] dan [E]. Fenom /e/ akan dilafalkan sebgai /e/ apabila muncul pada posisi terbuka, sedangkan dilafalkan sebagai [E] apabila munculnya pada posisi tutup, sebagai contoh:

\begin{tabular}{|l|l|l|l|}
\hline vokal & alogon & contoh & Silabe \\
\hline \multirow{4}{*}{ /e/ } & \multirow{3}{*}{$/ \mathrm{o} /$} & {$[$ ake] 'ini' } & Terbuka \\
\cline { 3 - 4 } & {$[$ rae]'sejenis ular' } & Terbuka \\
\cline { 3 - 4 } & {$[$ ede] 'itu' } & Terbuka \\
\cline { 2 - 4 } & \multirow{3}{*}{ /E/ } & {$[$ KalEte] 'sayap' } & Tertutup \\
\cline { 3 - 4 } & & {$[$ gEndi] 'terompah' } & Tertutup \\
\cline { 3 - 4 } & & {$[$ Empah] 'menambahkan' } & Tertutup \\
\hline
\end{tabular}

Vokal tengah-belakang yaitu /o/ memiliki dua alofon yaitu /o/ dan /D. Kedua realisai itu muncul masing masing pada silabe terbuka dan silabe tertutup, seperti pada data berikut

\begin{tabular}{|l|l|l|l|}
\hline vokal & alofon & Contoh & Silabe \\
\hline$/ \mathrm{o} /$ & $/ \mathrm{o} /$ & {$[$ roko $]$ 'daun' } & Terbuka \\
\hline & & {$[$ kalori 'muak' } & Terbuka \\
\hline & & {$[\mathrm{osu}]$ 'bekal' } & Terbuka \\
\hline & $/ \mathrm{D} /$ & {$[$ karPnto] 'kecil, tidak berisi } & Tertutup \\
\hline & & {$[$ IOnde] 'ikan bandeng' } & Tertutup \\
\hline & & {$[$ IOndo] 'gulung tembakau' } & Tertutup \\
\hline
\end{tabular}

Setelah mengindentifikasi keseluruhan Fenom vokal, dapat pula dijabarkan distribusinya. Distribusi adalah adanya kemungkinan masing-masing fonem baik, pada psosisi awal, tengah, dan akhir. Berikut disajikan distribusi fenom Vokal. 
/i/ : imbi 'percaya ', bilu 'miring', eli'suara'

/u/ : uhu 'kuku', budube ' mengomel', apu 'gempa'

/e/ : ese 'atas, esene 'hari senin', ale 'ayun'

/o/ : oru 'timba', bono 'gendut,engko 'mufakat'

/a/ : ai 'tali', hadi 'mendung', heba 'mendobrak'

\subsubsection{Konsonan Dialek Montong Krangbagik}

Dialek Mbojo Motontong Karangbagik memiliki 21 buah Konsonan. Adapun kedua puluh konsonan tersebut berdasarkan indentifikasi yang telah dilaksankan, yakni /n/, /w/, /h/, /d/,

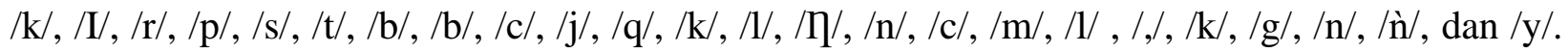
Penjelasan berikut adalah pasangan menimal dari masing-masing konsonan, kecuali konsonan /y/ yang tidak ditemukan pasangan minimalnya. Berikut uraian untuk memperjelas identidasnya sebagai sebuah fenom.

1. [bana] 'angsa' ............................../n/

[bawa] 'bawang' …........................./w/

2. [doho] 'duduk' ............................../h/

[dodo] 'permisi' .............................../d/

3. [ake] 'ini' ......................................../k/

[ale] 'ayun' ...................................../I/

4. [ara] 'hutan, datang' …......................../r/

[apa] ' lemak, angkat' ........................./p/

5. [asi] 'istana' ........................................../b/

[ati] 'alang alang, tidak' ........................./t/

6. [baba] 'ayah' ........................................./b/

[baba] 'membebat, tidak' .........................//

7. [baca] 'baca' .........................................../c/

[baja] 'menyiksa orang didepan ornag ramai' ................./j/

8. [baqa] 'mencaci' ........................................../q/

[baka] 'menghalau' .................................../k/

9. [bala] 'menghalau' ......................................./I/

[baja] 
Mabasan, Vol. 1, No. 2, Juli--Desember 2007: 63-77 
'mulut besar' .........................................../n/

10. [buni] 'jenjang pangkat' ........................../n/

[buci] 'cabut' ............................................/c/

11. [coma] 'membayar' ................................./I/

[cola] 'membayar' .................................../d/

12. [cidu] 'sekop' ......................................../k/

[culu] 'siku' ............................................/g/

13. [daga] 'dagangan' ..................................... $/ \mathrm{n} /$

[dana] 'tanah,negeri' ................................../n/

14. [ncaru] 'banyak' ...................................... $/ \mathrm{n} /$

[caru] 'bermalas-malasan ............................/Ø/

Terdapat dua buah konsonan yang dimiliki alofon, yakni komsonan /p/ dan /t/. Konsonan /p/ memiliki dua alofon, yakni /p/ dan /ph/. Konsonan /p/ dilafalkan sebagai /p/ apabila di posisi awal. Hal tersebut akan dipaparkan pada tabel berikut ini.

\begin{tabular}{|c|c|c|c|}
\hline Konsonan & Alovon & Contoh & Posisi \\
\hline \multirow{5}{*}{$/ \mathrm{p} /$} & \multirow[b]{2}{*}{$/ \mathrm{p} /$} & [rapu] 'rapat' & Tengah \\
\hline & & $\begin{array}{l}\text { [kabapa] } \\
\text { 'menggelepar' }\end{array}$ & Tengah \\
\hline & \multirow{3}{*}{$/ \mathrm{ph} /$} & [pahala] 'memukul' & Awal \\
\hline & & [phala] 'bebrapa' & Awal \\
\hline & & [phoda] 'benar' & Awal \\
\hline
\end{tabular}

Kojnsonan /t/ memili dua alofon, yakni [t] dan [th]. Konsonan [t] akan dilafalkan sebagai [t] apabila pada posisi tengah dan akan dilafalkan sebagai [th] apabila berada pada posisi awal. Hal tersebut akan dipaparkan pada tabel berikut ini.

\begin{tabular}{|l|l|l|l|}
\hline Konsonan & Alofon & Contoh & posisi \\
\hline \multirow{4}{*}{$/$ t/ } & /t/ & {$[$ phata] 'kenal' } & Tengah \\
\cline { 3 - 4 } & \multirow{2}{*}{$/$ boto] 'boto' } & Tengah \\
\cline { 2 - 4 } & \multirow{2}{*}{ thako] 'batang' } & Awal \\
\cline { 3 - 4 } & $\begin{array}{l}{[\text { thapa }]} \\
\text { 'menghalangi' }\end{array}$ & Awal \\
\hline
\end{tabular}


Keunikan konsonan pada dialek ini dalah bunyi bilabial hambar bersuara tanpa aspirasi, yaitu /b/, juga terdapat bunyi hambatan bersuara inspirasi /Б/. Sebagai contoh berikut adalah pasangan minimal antara kedua fwnwem tersebut.

$$
\begin{aligned}
& \text { [baba] 'ayah' } \\
& \text { [baba] 'membebat' } \\
& \text { [baca] 'maca' } \\
& \text { [baca 'bekas, hash perbuatan' }
\end{aligned}
$$

Begitu pula terdapat konsonan apikoalveolar hambat bersuara /d/ tanpa aspirat dan konsonan apikoaveolar hambat bersuara beraspirasi /d/. Sebagai contoh berikut adalah pasangan antara dua fenom tersebut.

$$
\begin{aligned}
& \text { [da] 'tidak' } \\
& \text { [da] 'lagi' } \\
& \text { Telah utara'[ama] 'damar' } \\
& \text { [dama] 'memegang' } \\
& \text { [dari] 'keturunan' } \\
& \text { [aril] 'mengiris, iris' } \\
& \text { [darn] 'mengiris, iris' } \\
& \text { [dparo] 'meraba-raba }
\end{aligned}
$$

Konsonan glotal /q/ dengan /k/ merupakan dua fonem yang berada dan sangat produktif. Sebagai contoh berikut adalah pasangam minimal antara kedua fenom tersebut.

[kakiki] 'berbunyi seperti bunyi

[anak ayam' [kakiqi] jenis tumbuhan

Perdu untuk sayur' [kafiki]

'memincingkan mata' [kafigi]

'mengempiskan'

[per]' pr,

[fiqi] 'mengerut' 
Ciri lain dari dialek ini adalah bahasa vokalis, yakni suara konsonan tidak muncul pada posisi akhir. Konsonan hanya muncul pada awal dan posisi tengah.

\section{Penutup}

\subsection{Simpulan}

Berdasarkan pendekatan dialektologis, telah diperoleh 157 buah peta perbedaan unsure kebahasaan (fonologi dan leksikon), yang dikumpulkan pada lima daerah pengamatan. Secara sinkronis, pengolompokan daerah-daerah pengamatan yang bertetangga ke dalam daerah dialek atau subdialek didasarkan pada analisis dialektometri. Berdasarkan analisis tersebut, BMbS terbagi dalam dua dialek, yaitu:

1) Dialek Mbojo Karangbagik (DMbMK)

Dialek Mbojo Montong Karangbagik (DMbMK) menurunkan dua subdialek MbMontong dan subdialek MbKarangbagik. Selanjutnya, subdialek MbKarangbagik menurunkan Usar (MbUs) dan hijrah $(\mathrm{MbHj})$.

2) Dialek Mbojo Labuan Bontong (DMbLB).

\subsection{Saran}

Penelitian ini masih merupakan awal dari penelitian yang lebih dari lanjut. Dampak yang diharapkan dari penelitian ini adalah semakin tergalinya bahasa-bahasa nusantara pada umumnya dan Bahasa Mbojo pada khususnya. Selain itu, diharapkan penelitian ini menjadi upaya inventarisasi bahasa-bahasa di Indonesia. Mengingatkan hal-hal tersebut, maka penelitian tentang Bahasa Mbojo masih sangat terbuka untuk dilakukan lebih dari lanjut. 


\section{DAFTAR PUSTAKA}

Akhmad. 1998. "Variasi Leksikon Bahasa Bima". Denpasar: Tesis S2 Liguistik Universitas Udayana.

Burhanudin. dkk. 2005. "Kontak Bahasa antara Bahasa Sumbawa di Lombok Timur dengan Bahasa Sasak ”. Laporan Akhir Penelitian Kelompok: Kantor Bahasa Provinsi NTB.

Herisantoso, Suparman. dkk. 1997. Pemetaan Bahasa-Bahasa di Nusa Tenggara Barat. Jakarta: Pusat Pembinaan dan Pengembangan Bahasa.

Mad'ie, Abdul Chaer. 1986. "Buku Materi Pokok Kebahasaan”. Universitas Terbuka

Mahsun. 199. Dialektologi Diakronis: Sebuah Pengantar. Yokyakarta: Gajah madaUnirversity Press.

Mahsun. 2005. Metode Penelitian Bahasa: Tahapan, Strategi, Metode, dan Tekniknya. Jakarta: Raja Grafindopersada.

Mahsun. 2006. Kajian Dialektologi Diakronis Bahasa Sasak di Pulau Lombok. Yokyakarta: Gama Media.

Rachan, HA, Abdul. 1995. "Sistem Morfologi Kata Kerja Bahasa Bima". Jakarta: Pusat Pembinaan dan Pengembangan Bahasa.

Sudika, I Nyoman. 1998. "Isolek Bahasa Bali di Lombok: Kajian Dialektologi Diakronis“. Denpasar: Tesis S-2 Universitas Udayana.

Tama, I Wayan. dkk. 1996. Fonologi Bahasa Bima. Jakarta: Pusat Pembinaan dan Pengembangan Bahasa. 